\title{
Hemodialysis, Membrane-Related Neutrophil Dysfunctions, and Pentoxifylline - A Pilot Study
}

\author{
M. Spannagl ${ }^{1}$, H. Schiff1 ${ }^{1}$, H. Hoffmann ${ }^{2}$, and M. Jochum ${ }^{3}$ \\ ${ }^{1}$ Medizinische Klinik Innenstadt, ${ }^{2}$ Chirurgische Klinik Großhadern, \\ ${ }^{3}$ Abteilung für klinische Chemie und Biochemie in der Chirurgischen Klinik Innenstadt, Ludwig-Maximilians-Universität München
}

Summary. Hemodialysis treatment is associated with activation of neutrophil granulocytes. Pentoxifylline has been shown to inhibit neutrophil activation in vitro and in vivo. We investigated the effect of pentoxifylline on leukocyte and platelet counts and on plasma levels of extracellularly released neutrophil elastase and lactoferrin during a four-hour hemodialysis treatment. Eight patients received $400 \mathrm{mg}$ of pentoxifylline or placebo orally twice a day over 14 days and an additional dose of $400 \mathrm{mg}$ of pentoxifylline intravenously during hemodialysis. Each subject served as his own control in a randomized, double-blind, cross-over study. Combined oral and intravenous treatment with pentoxifylline prevented neither leukopenia nor neutrophil degranulation during the time interval studied. Elastase plasma levels paralleled the drop in leucocyte counts and thereafter increased similarly in both groups. Lactoferrin plasma levels exhibited less increase in the treated group; however, this effect was not statitistically significant. This may be due to the small number of cases studied and to difficulties in reaching effective plasma levels without side effects.

Key words: Hemodialysis - Neutrophils - Elastase - Lactoferrin - Pentoxifylline

End-stage renal disease patients undergoing hemodialysis treatment with cellulose-based membranes (especially cuprophane) experience intense blood/

Abbreviations: $\mathrm{PTX}=$ pentoxifylline; $\mathrm{PAF}=$ platelet activating factor; $\mathrm{WBC}=$ white blood cell; $\mathrm{AD}_{50}=50 \%$ attenuative dose; $\mathrm{TNF}=$ tumor necrosis factor membrane interactions. During cuprophane hemodialysis numerous neutrophil dysfunctions may occur due to activation by complement split-products (C3a, C5a) and/or arachidonic acid metabolites [2, $3,17]$. Sequestration of activated neutrophils into the pulmonary capillaries causes profound systemic leukopenia during the early phase of hemodialysis [3]. Sixty to 120 minutes after initiation of hemodialysis there is a rebound leukocytosis that has been attributed to the return of neutrophils from the lungs into the circulation as well as to bone marrow release of immature neutrophils. Moreover, neutrophils remaining in the peripheral circulation during the cuprophane membrane-related neutropenic phase are functionally altered as compared to predialysis neutrophils in the same patient. The abnormal functional responses include decreased chemotaxis, increased aggregation, increased adherence, and degranulation $[6,12]$. Pentoxifylline (1-(5oxohexyl)-3,7 dimethylxanthine) (PTX) has been shown to inhibit several neutrophil functions in vitro, including chemotaxis, oxidant production, and the priming of neutrophils by platelet activating factor (PAF) $[1,7,19]$. PTX in vitro also suppressed the release of endotoxin-induced tumor necrosis factor (TNF) from macrophages [18]. Furthermore, a protective effect of PTX was demonstrated in animal models of endotoxin-induced acute lung injury [8]. These data suggest that the concept of modulation of neutrophil and macrophage function by PTX seems to be an interesting approach in inflammatory diseases. We therefore examined the effects of PTX on hemodialysisrelated neutrophil dysfunctions in a randomized, double-blind, cross-over pilot study. In particular, we were interested in evaluating drug concentrations high enough to protect neutrophils from activation. 


\section{Patients and Methods}

\section{Patients}

The pilot study incuded eight patients (4 females, 4 males; mean age $51 \pm 7$ years) with end-stage renal disease, who had been on maintenance hemodialysis for at least three months. Three out of eight patients suffered from diabetic nephropathy, three from chronic glomerulonephritis, and two from chronic interstitial nephritis. None of the patients had a history of allergic reactions or clinical evidence of acute inflammation. None were taking drugs known to affect neutrophil production, function, or kinetics. All patients had normal white blood cell (WBC) and differential cell counts. Routine dialysis techniques were employed and the patients underwent four hours of bicarbonate hemodialysis three times a week. The cuprophane hollow fiber dialyzer from Hospal (Disscap $110 \mathrm{E}$ containing $1.1 \mathrm{~m}^{2}$ surface) was used. Informed consent was obtained from all paticipating subjects prior to the study.

\section{Study Design and Blood Sampling}

The patients were randomly assigned to receive either $400 \mathrm{mg}$ of PTX or matched placebo orally twice a day over 14 days following a two-week washout period in a blind cross-over design. The measurements took place at the end of the placebo or treatment phase during two comparable hemodialysis sessions. In addition, PTX or saline was given as a bolus injection of $100 \mathrm{mg}$ intravenously before dialysis followed by a continuous infusion of $300 \mathrm{mg}$ over 3 hours. WBC, differential, and platelet counts and plasma levels of neutrophil elastase and lactoferrin were investigated. Predialysis blood samples were drawn from the arteriovenous fistula before heparinization. Subsequent samples were taken from the venous line of the dialyzer at 10,20, 30 and 240 minutes after initiation of hemodialysis. Citrated whole blood was immediately spun down. Plasma aliquots were stored at $-80^{\circ} \mathrm{C}$ until measurement.

\section{Determination of Blood Cells and Neutrophil Proteins}

WBC, platelet, and differential counts were determined by an automatic blood cell counter (Sysmex). Plasma levels of both neutrophil elastase in complex with $\alpha 1$ proteinase inhibitor and neutrophil lactoferrin were determined employing highly sensitive enzyme-linked immunoassays $[15,16]$.

\section{Statistical Analysis}

Data are presented as median \pm SEM. Student's $t$ test for paired data was used to test for statistically significant differences between treatment groups, or for changes within a group. A $p$-value less than 0.05 was considered significant.

\section{Results}

Oral PTX given in doses of $800 \mathrm{mg} /$ day was well tolerated by all patients. However, additional intravenous PTX $(400 \mathrm{mg} / 3 \mathrm{~h})$ induced nausea in three out of eight cases. Six different time intervals were chosen to represent different phases in neutrophil kinetics and functions during the course of cuprophane hemodialysis. Oral PTX treatment (Table 1) did not significantly alter predialytic WBC, neutrophil, and platelet counts as well as plasma levels of neutrophil elastase and lactoferrin.

In the placebo group the WBC count dropped to a minimum of $2900 \pm 300 / \mu l$ at 20 minutes $(p<$ $0.0001)$; thereafter the WBC count showed a steady rise, reaching $3900 \pm 900 / \mu \mathrm{l}$ at 30 minutes and $10200 \pm 1000 / \mu 1$ at 4 hours. Neutrophil counts closely paralleled the changes in WBC counts, whereas lymphocyte counts did not change. PTX treatment neither prevented nor significantly modified the leukopenic response (Fig. 1 a).

In the placebo group plasma levels of neutrophil elastase dropped significantly $(p<0.01)$ from $181 \pm 25 \mathrm{ng} / \mathrm{ml}$ before dialysis to $141 \pm 21 \mathrm{ng} / \mathrm{ml}$ at 20 minutes. Thereafter, plasma levels of neutrophil elastase increased significantly $(p<0.001)$ to $322 \pm 72 \mathrm{ng} / \mathrm{ml}$ at 4 hours. PTX treatment did not exhibit a statistically significant effect on plasma levels of neutrophil elastase during dialysis (Fig. 1c).

Measurements of lactoferrin plasma levels during cuprophane hemodialysis revealed that this neutrophil lysosomal protein was more rapidly released than neutrophil elastase. Lactoferrin plasma levels in the placebo group increased from $220 \pm 28 \mathrm{ng} / \mathrm{ml}$ before dialysis to $400 \pm 57 \mathrm{ng} / \mathrm{ml}$ at

Table 1. Predialytic parameters in eight patients undergoing chronic hemodialysis treatment with and without PTX administration in a randomized cross-over protocol (median \pm SEM)

\begin{tabular}{lcr}
\hline & Control group & PTX group \\
\hline Leukocytes $\left[\times 10^{3} / \mu \mathrm{l}\right]$ & $8.0 \pm 1.0$ & $7.3 \pm 1.0$ \\
Neutrophils $[\%]$ & $67.9 \pm 2.1$ & $65.9 \pm 2.1$ \\
Platelets $\left[\times 10^{3} / \mu 1\right]$ & $257 \pm 22$ & $284 \pm 20$ \\
Elastase $[\mathrm{ng} / \mathrm{ml}]$ & $181 \pm 25$ & $224 \pm 42$ \\
Lactoferrin $[\mathrm{ng} / \mathrm{ml}]$ & $220 \pm 29$ & $235 \pm 49$ \\
\hline
\end{tabular}



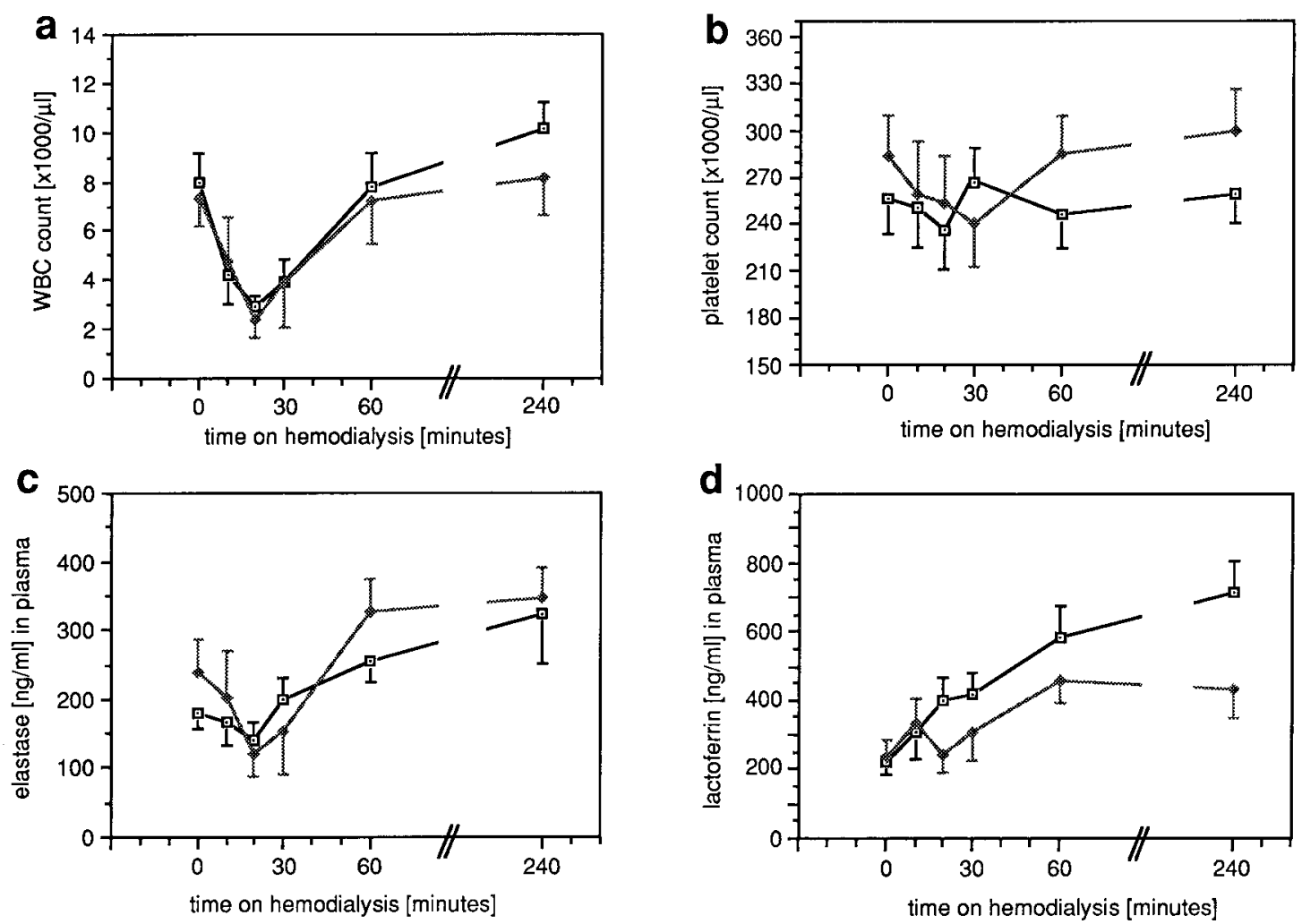

Fig. 1. Time course of leukocyte count (a), platelet count (b), and elastase (c) and lactoferrin (d) plasma levels during hemodialysis treatment. Median \pm SEM of eight patients are shown during a control phase (solid line) and application of PTX (shaded line)

20 minutes $(p<0.003)$, followed by a further increase to $710 \pm 88 \mathrm{ng} / \mathrm{ml}$ at the end of the dialysis session. PTX treatment attenuated the increase of lactoferrin in plasma to $460 \pm 64 \mathrm{ng} / \mathrm{ml}$ at $60 \mathrm{~min}-$ utes $(p<0.05)$ and $430 \pm 74 \mathrm{ng} / \mathrm{ml}$ at the end of the hemodialysis session. Compared to the control group, however, this effect was not statistically significant (Fig. 1d).

Platelet counts were not significantly altered either during the course of hemodialysis treatment or by the administration of PTX (Fig. 1 b).

\section{Discussion}

Exposure of blood to the cuprophane membrane during clinical hemodialysis caused profound but transient neutropenia and a release of neutrophilderived elastase and lactoferrin in our patients. The time course of elastase plasma levels was paralleled by the initial drop in leukocyte counts. Lactoferrin, however, showed a continuous increase until the end of the hemodialysis treatment. These major results of our investigation provide additional support for the concept that sequestration of primed neutrophils into the microcirculation of the lungs and release of neutrophil components upon stimulation are interlinked pathophysiological mechanisms which play an important role in acute and permanent deterioration of neutrophil functions and neutrophil death during cuprophane hemodialysis $[5,10]$. Neutrophil dysfunctions are the measurable consequences of a complex series of activatd pathways including the complement cascade and arachidonic acid metabolism. The clinical relevance of these phenomena and their long-term sequelae are not yet fully unterstood [4]. However, it is likely that cyclic neutropenia and adversely affected neutrophil functions may contribute to the increased infection rate in dialysis patients. The local imbalance of high amounts of released cell proteinases and their extracellularly available proteinase inhibitors may favor the development of pulmonary disease in long-term hemodialysis patients [9].

PTX has been shown to inhibit several neutrophil functions in vitro after activation by potent stimuli [7]. In our study, conventional doses of oral PTX (800 mg daily) and a continuous infusion of $400 \mathrm{mg}$ during hemodialysis did not exhibit a striking effect on cuprophane membrane-related neu- 
tropenia and neutrophil degranulation. Furthermore, the bolus injection of $100 \mathrm{mg}$ of PTX before hemodialysis followed by a continuous infusion of $100 \mathrm{mg} / \mathrm{h}$ over 3 hours induced nausea in three of eight patients.

The attenuated release of lactoferrin, a lysosomal protein of specific granules, may hint at a proposed mode of PTX action. Unlike elastase of azurophilic granules, lactoferrin is readily released by soluble stimuli (e.g., PAF, C5a, endotoxin) [11]. PTX may therefore have prevented the discharge of specific neutrophil granules at least to some extent in our patients. Our findings are in contrast to the data from in-vitro experiments, but are in agreement with preliminary observations in other studies $[13,14]$ that showed no striking modification of cuprophane membrane-induced neutropenia by PTX during hemodialysis treatment. This apparent discrepancy between experimental and clinical studies may be explained by differences in the applied drug concentrations. Peak plasma levels after an oral dose of $100 \mathrm{mg}$ of PTX amount to 3 to $5 \mu \mathrm{mol} / 1$, several active metabolites may reach slightly higher plasma levels [20]. Under invitro conditions, however [7], neutrophil aggregation and augmentation of their adherence was only modestly inhibited by much higher PTX concentrations $\left(\mathrm{AD}_{50 \%} 1 \mathrm{mmol} / 1\right.$ or $\mathrm{AD}_{50 \%}>240 \mu \mathrm{mol} /$ 1, respectively). Thus Hammerschmidt et al. [7] considered in vitro drug effects with $\mathrm{AD}_{50 \%}$ $>50 \mu \mathrm{mol} / 1$ unlikely to be of chlinical importance. On the other hand, Sullivan et al. were able to demonstrate that much lower concentrations of PTX reduced cytokine-induced granulocyte migration [19]. Another recent study showed that conventional doses of PTX reduced endotoxin-induced TNF release in healthy normal subjects [21]. These findings suggest that distinct leukocyte functions may be inhibited at different PTX concentrations. Moreover, the inhibitory effect of PTX may depend on the activating stimulus. We conclude that pretreatment with conventional doses of PTX results in drug concentrations which are not high enough to prevent significantly the neutrophil activation which occurs during cuprophane hemodialysis.

\section{References}

1. Bessler H, Gilgal R, Djaldetti M, Zahavi I (1986) Effect of pentoxifylline on the phagocytotic activity, cAMP levels, and superoxide anionproduction by monocytes and polymorphonuclear cells. J Leuc Biol 40:747-754

2. Betz M, Haensch G, Rautenberg E, Bommer J, Ritz E
(1988) Cuprammonium membranes stimulated interleukin 1 release and arachidonic acid metabolism in monocytes in the absence of complement. Kidney Int 34:67-73

3. Craddock P, Fehr J, Dalmasso A, Brigham K, Jacob H (1977) Hemodialysis leukopenia: pulmonary leukostasis resulting from complement activation by dialysis cellophane membranes. J Clin Invest 59:879-888

4. Hakim R (1986) Clinical sequelae of complement activation in hemodialysis. Clin Nephrol 26 (Suppl 1):9-12

5. Hällgren R, Venge B, Wikstroem B (1981) Haemodialysis induced increase in serum lactoferrin and serum eosinophil cationic protein as signs of local neutrophil and eosinophil degranulation. Nephron 29:233-238

6. Hammerschmidt D, Goldberg R, Raij L, Kay N (1985) Leukocyte abnormalities in renal failure and hemodialysis. Sem Nephrol 5:91-103

7. Hammerschmidt D, Kotasek D, McCarthy T, Huh P, Freyburger G, Vercellotti G (1988) Pentoxifylline inhibits granulocyte and platelet functions, including granulocyte priming by platelet activating factor. J Lab Clin Med 112:254263

8. Hoffmann H, Hatherill J, Yonemaru M, Crowley J, Zheng H, Ishizaka A, Raffin T (1990) Early posttreatment with pentoxifylline or dibutyryl cyclic AMP attenuates E. coliinduced acute lung injury in guinea pigs. Am Rev Respir Dis (in press)

9. Hörl W, Jochum M, Heidland A, HF (1983) Release of granulocyte proteinase during hemodialysis. Am J Nephrol $3: 213-217$

10. Hörl W, Riegel W, Schollmeyer P (1987) Plasma levels of main granulocyte components in patients dialysed with polycarbonate and cuprophane membranes. Nephron $45: 272-276$

11. Jochum M, Dwenger A (1986) Sequential release of lysosomal inflammation mediators and chemiluminescence response of stimulated polymorphonuclear leukocytes. Fresenius Z Anal Chem 324:362-363

12. Lewis S, Van Epps D (1987) neutrophil and monocyte alterations in chronic dialysis patients. Am $\mathbf{J}$ Kidney Dis $9: 381-395$

13. Lowe C, Simpson K, Lennie S, Travers M, Wallace M, Baird J, Allison M, Schönharting M (1989) Pentoxifylline in patients undergoing haemodialysis. Second international conference on leukocyte function, Nice, France

14. Mery J, Stamatakis G, Fessi H, Pham Huu T, Pasquier C, Chollet-Martin S, Pocidalo M, Hakim J (1989) Can pentoxifylline prevent adverse reactions to hemodialysis membranes. Second international conference on leukocyte function, Nice, France

15. Neumann S, Jochum M (1984) Elastase-1-proteinase inhibitor complex. In: Bergmeyer H, Bergmeyer J, Graß1 M (ed) Methods of enzymatic analysis, Verlag Chemie, Weinheim, pp 184-195

16. Rautenberg W, Neumann S, Gunzer G, Lang H, Jochum M, HF (1986) Quantitation of human lactoferrin as an inflammation marker by an enzyme-linked immunosorbent assay (ELISA). Fresenius Z Anal Chem 324:364

17. Schiffl H, Strasser T, Hohnloser J, Weber P (1989) Hemodialysis associated neutrophil abnormalities and generation of leukotriene B4. In: Andreucci V, Dal Canton A (eds) Current therapy in nephrology, Klüwer Academic Publishers, Norwell, pp 303-305

18. Strieter R, Remick D, Ward P, Spengler R, Lynch J, Larrick J, Kunkel S (1988) Cellular and molecular regulation of tumor necrosis factor production by mononuclear cells. Biochem Biophys Res Com 155:1230-1236

19. Sullivan G, Carper H, Novick W, Msandell G (1988) Inhibi- 
tion of the inflammatory action of interleukin 1 and tumor necrosis factor (alpha) on neutrophil function by pentoxifylline. Infect Immun 56:1722-1729

20. Ward A, Clissold S (1987) Pentoxifylline. A review of its pharmacodynamic and pharmacokinetic properties, and its therapeutic efficacy. Drugs 34:50-97

21. Zabel P, Schönharting MM, Wolter DT, Schade UF (1989) Oxpentifylline in endotoxinaemia. Lancet II : 1474-1477
Received: January 26, 1990

Returned for revision: April 6, 1990

Accepted: June 20, 1990

Dr. M. Spannagl

Medizinische Klinik Innenstadt

Ziemssenstr. 1

D-8000 München 2

\section{Buchbesprechungen}

G. Möller (Ed.) Immunobiology of parasites. (Immunological Reviews, vol. 112) Munksgaard, Copenhagen 1989. 208 pages, Subscription price 1989 (6 volumes per year): DKK 1440.00 including postage. USA, Canada and Japan: DKK 1500.00 including postage and air freight.

Dieser Band enthält 9 Beiträge, von denen 8 der Immunobiologie parasitärer Infektionen gewidmet sind. Ein weiterer Beitrag befaßt sich mit den Interaktionen zwischen Mykoplasmen und dem Immunsystem. - Obwohl Parasitosen weltweit zu den wichtigsten Erkrankungen zählen, war die Erforschung der molekularen Grundlagen ihrer immunologischen und biochemischen Regulations- und Pathomechanismen lange Zeit ein vernachlässigtes Gebiet. Dies hat sich in den letzten Jahren grundlegend geändert; vor allem aufgrund der Erkenntnis, daß Strategien zur Entwicklung wirksamer Vakzinen ein besseres Verständnis dieser Mechanismen voraussetzen. - Ein Übersichtsartikel von A. Capron zur ,molekularen Basis der WirtParasit-Beziehung" legt mit Hilfe zahlreicher Beispiele den Wissensstand über Infektions- und Evasionsmechanismen, Immunantwort und protektive Antigene bei den wichtigsten Parasitosen dar. Scott et al. geben eine Übersicht zur Rolle von Zytokinen und CD4 + T-Lymphozyten bei der Regulation von Parasit/Wirt-Gleichgewicht, Immunität und Pathogenese. Sie zeigen an den Beispielen der experimentellen Leishmaniasis und Schistosomiasis, daß TH-1 Zellen durch die Produktion von IL-2 und IFN- $\gamma$ entscheidend an Kontrolle und Protektion beteiligt sind, während TH-2 Aktivität, Interleukin 3, 4 und 5 mit Empfänglichkeit und Immunpathologie assoziiert sind. Eine weitere Heterogenität der Rolle von Zellen mit TH-1 funktionellem Phänotyp weisen Müller et al. in ihren Untersuchungen parasitenspezifischer T-Zell Klone beim Leishmania-majorModell nach. Minoprio et al. diskutieren die Mechanismen der ausgeprägten unspezifischen ,panklonalen“ Aktivierung von Bund T-Zellen und die selektive Stimulation von TCRI T-Zellen bei der murinen Trypanosoma-cruzi-Infektion. - Ein Übersichtsartikel von Grau et al. faßt die experimentellen und klinischen Daten zusammen, die die besondere Bedeutung von TNF und anderen Zytokinen (GM-CSF, IL-3, IFN- $\gamma$ ) bei der Pathogenese der zerebralen Malaria belegen. Zudem wird die Regulation dieser Zytokin-Kaskade durch CD4+ T-Zellen im Modell beschrieben. Langhorne et al. zeigen die essentielle Rolle von CD4 + T-Zellen für die Entstehung einer protektiven Immunität im Plasmodium-chabaudi-Modell. - Ein weiterer Beitrag beschreibt die Charakterisierung immunodominanter BZell-Epitope am Beispiel eines protektiven Zielantigens von Plasmodium falciparum (Pf155/RESA) sowie die Bedeutung der für eine ausreichende Immunogenität erforderlichen T-Zell-Epitope und deren ausgeprägte MHC-Restriktion. Schließlich wird am Beispiel der Hühner-Kokzidiose durch Eimeria tenella über die Verwendung von anti-Idiotyp Antikörpern als Surrogatantigen prädominanter T-Zell-Epitope berichtet. - Zusammenfassend gibt der vorliegende Band eine ausgezeichnete Übersicht zum aktuellen Wissen über die Rolle verschiedener T-Zellpopulationen und Zytokine bei der Pathogenese, Regulation und protektiven Abwehr der wichtigsten Parasitosen sowie über Strategien und Probleme bei der Definition protektiver Antigene. Der Band ist sehr empfehlenswert für parasitologisch interessierte Immunologen und für diejenigen, die auf dem Gebiet der Zytokine arbeiten, aber auch für andere parasitologisch bzw. tropenmedizinisch interessierte Mediziner und Naturwissenschaftler.

Th. Löscher (München)

V. Diehl, M. Pfreundschuh, M. Loeffler (Eds.) New Aspects in the Diagnosis and Treatment of Hodgkin's Disease. (Recent Results in Cancer Research, Vol. 117) Springer, Berlin Heidelberg New York London Paris Tokyo Hong-Kong 1989. XIV, 283 S., 71 Abb., 91 Tab., Hard cover DM 178,-

Das in der bekannten Reihe Recent Results in Cancer Research erschienene Buch von Diehl, Pfreundschuh und Löffler beschäftigt sich auf 283 Seiten sehr sorgfältig und ausführlich mit aktuellen Problemen des Morbus Hodgkin. Es ist den Autoren gelungen, von nahezu allen international bedeutenden Kennern der Lymphogranulomatose Beiträge aus ihrem Spezialgebiet zusammenzufassen. Die ersten 100 Seiten des Buches beschäftigen sich mit neuen Erkenntnissen auf dem Gebiete der zellularen Pathologie, der Genetik und der immunbiologischen Erforschung der Hodgkinzellen und der Sternberg-Reed'schen Riesenzellen. - Es folgt ein kurzer Abschnitt über neue diagnostische Möglichkeiten des Morbus Hodgkin mit monoklonalen Antikörpern sowie allgemein über diagnostische Strategien und Staging-Verfahren beim Morbus Hodgkin. - Den breitesten Raum nimmt naturgemäß die Therapie der Lymphogranulomatose ein. Nach zwei klaren einführenden Übersichtsreferaten über die Radiotherapie des Morbus Hodgkin von H. Sack sowie dem aktuellen Stand der Chemotherapie des Morbus Hodgkin von P.H. Wirnick folgen aktuelle Ergebnisse und Berichte abgeschlossener und zum Teil noch laufender Therapiestudien aus verschiedenen bedeutenden Therapiezentren der Welt, mit besonderer Berücksichtigung des experimentellen Therapieansatzes der Knochenmarktransplantation. - Die Beiträge der einzelnen Autoren sind in der Regel kurz und übersichtlich. Sie enthalten in den meisten Fällen eine knappe, prägnante Zusammenfassung für den schnellen Leser. Besonders erfreulich auch die letzten beiden Kapitel, in denen eingehend über Lebensqualität der Patienten unter Therapie als auch auf die Problematik der Sekundär-Neoplasien nach Therapie eingegangen wird. Aufgrund der ausführlichen und zum Teil sehr differenzierten und speziellen Darstellung der unterschiedlichsten Probleme der Diagnostik und Therapie des Morbus Hodgkin dürfte das vorliegende Werk einen breiten Kreis experimentell und klinisch tätiger Onkologen ansprechen. Es bietet jedoch auch jedem interessierten onkologisch tätigen Arzt eine gute Gelegenheit, sein Wissen über die Lymphogranulomatose zu aktualisieren und zu vertiefen. Umfangreiche Literaturhinweise geben dem Leser zusätzlich Möglichkeiten, ganz spezielle Fragestellungen weiter zu verfolgen. Insgesamt ein weiteres empfehlenswertes Buch aus der bekannten onkologischen Reihe des Springer-Verlages.

M. Winkelmann (Düsseldorf) 